\title{
Mechanisms of Induction and Expression of Long-Term Depression at GABAergic Synapses in the Neonatal Rat Hippocampus
}

\author{
Olivier Caillard, Yehezkel Ben-Ari, and Jean-Luc Gaïarsa \\ Institut de Neurobiologie de la Mediterranée (INMED), Institut National de la Santé et de la Recherche Médicale U29, B.P. \\ 13, 13273 Marseille Cedex 09, France
}

Synaptic plasticity at excitatory glutamatergic synapses is believed to be instrumental in the maturation of neuronal networks. Using whole-cell patch-clamp recordings, we have studied the mechanisms of induction and expression of longterm depression at excitatory GABAergic synapses in the neonatal rat hippocampus ( $\left.L T D_{G A B A-A}\right)$. We report that the induction of $L_{T D} D_{G A B A-A}$ requires a $G_{A B A}$ receptor-mediated membrane depolarization, which is necessary to remove the $\mathrm{Mg}^{2+}$ block from postsynaptic NMDA receptors. $L T D_{\mathrm{GABA}-\mathrm{A}}$ is associated with an increase in the coefficient of variation of evoked $\mathrm{GABA}_{\mathrm{A}}$ receptor-mediated synaptic currents and a decrease in the frequency, but not amplitude, of $\mathrm{Sr}^{2+}$-induced asynchronous $\mathrm{GABA}_{\mathrm{A}}$ quantal events. We conclude that LTD $_{\text {GABA-A }}$ induction requires the activation of both GABA $_{A}$ and NMDA postsynaptic receptors and that its expression is likely presynaptic.

Key words: synaptic plasticity; development; GABA; glutamate; calcium; hippocampus
Long-term potentiation (LTP) and long-term depression (LTD) are persistent activity-dependent increases or decreases in the strength of synaptic efficacy. Both LTP and LTD are cellular processes frequently associated with memory (Bear and Malenka, 1994), with the hyperexcitability observed in pathological states (Ben-Ari and Represa, 1990; Crepel et al., 1993) or with the establishment of appropriate synaptic connections in the developing brain (Constantine-Paton and Cline, 1998; Fitzsimonds and Poo, 1998). The mechanisms leading to long-term changes in synaptic strength have been extensively studied at glutamatergic excitatory synapses (Bear and Malenka, 1994). However, activitydependent modulations of GABAergic synapses would also have important consequences on brain development and physiological functions. The study of the mechanisms involved in the modulation of GABAergic synaptic efficacy is therefore crucial for our understanding of both physiological and pathological plasticity.

Both LTP and LTD have been reported to occur at adult GABAergic synapses in different mammalian brain regions. These two forms of long-term changes in GABAergic efficacy are accounted for by an upregulation (Kano et al., 1992; Nusser et al., 1998) or a downregulation (Stelzer et al., 1987; Morishita and Sastry, 1996) in the sensitivity or the number of postsynaptic $\mathrm{GABA}_{\mathrm{A}}$ receptors at functional synapses. Although a transient rise in intracellular calcium concentration $\left(\left[\mathrm{Ca}^{2+}\right]_{\mathrm{i}}\right)$ appears to be important in shaping the strength of GABAergic synapses, the source of calcium may differ. GABAergic LTP in Purkinje cells

\footnotetext{
Received May 7, 1999; revised June 21, 1999; accepted June 23, 1999.

This work was supported by the Institut National de la Santé et de la Recherche Médicale. O.C. was a recipient of a doctoral fellowship from the Ministère de l'Enseignement Supérieur et de la Recherche. We thank Drs. L. Aniksztjen, C. Bernard, V. Crépel, and J. Hirsch for helpful comments and critical reading of this manuscript.

Correspondence should be addressed to Dr. Jean-Luc Gaïarsa, Institut de Neurobiologie de la Mediterranée (INMED), Institut National de la Santé et de la Recherche Médicale U29, Avenue de Luminy, B.P. 13, 13273 Marseille Cedex 09, France.

Dr. Caillard's present address: Arbeitsgruppe Zellular Neurbiologie, Max-Plank Institut für Biophysikalische Chemie, Am Fasseburg, 37077 Gottingen, Germany. Copyright (C) 1999 Society for Neuroscience $0270-6474 / 99 / 197568-10 \$ 05.00 / 0$
}

results from the activation of voltage-dependent calcium channels (Kano et al., 1992), whereas in cortical neurons calcium release from postsynaptic internal calcium stores is involved (Komatsu, 1996). In both hippocampal (Stelzer et al., 1987) and cortical pyramidal neurons (Komatsu and Iwakiri, 1993), the induction of GABAergic LTD results from an influx of calcium through NMDA receptor-gated channels. In the later studies, the activation of AMPA receptors (Stelzer et al., 1987) or blockade of $\mathrm{GABA}_{\mathrm{A}}$ receptor-mediated inhibition (Komatsu and Iwakiri, 1993) was necessary for the induction of LTD.

A different situation prevails in the developing brain because GABA provides a depolarizing action sufficient to activate voltage-dependent $\mathrm{Na}^{+}$and $\mathrm{Ca}^{2+}$ conductances and to remove the $\mathrm{Mg}^{2+}$ block from NMDA channels (Ben-Ari et al., 1997). In a previous study, we reported that early in development GABAergic synaptic transmission expresses bi-directional plasticity in the neonatal rat hippocampus (McLean et al., 1996). Thus, high frequency stimulation of the GABAergic and glutamatergic fibers leads to an LTD of evoked $\mathrm{GABA}_{\mathrm{A}}$ receptormediated synaptic responses $\left(\mathrm{LTD}_{\mathrm{GABA}-\mathrm{A}}\right)$, whereas in the presence of NMDA receptor antagonists, the same protocol leads to LTP $_{\text {GABA-A }}$.

In the present study we have characterized the mechanisms required for the induction of $\mathrm{LTD}_{\mathrm{GABA}-\mathrm{A}}$ and determined its locus of expression. We report that at the postsynaptic level, $\mathrm{LTD}_{\mathrm{GABA}-\mathrm{A}}$ induction requires a $\mathrm{GABA}_{\mathrm{A}}$ receptor-mediated depolarization that removes the magnesium block from NMDA channels leading to a calcium influx through these channels. The increase in the coefficient of variation $(\mathrm{CV})$ of evoked $\mathrm{GABA}_{\mathrm{A}}$ receptor-mediated postsynaptic currents and the decrease in the frequency of $\mathrm{Sr}^{2+}$-induced asynchronous quantal GABA release strongly support a presynaptic locus for the expression of LTD $_{\text {GABA-A }}$.

\section{MATERIALS AND METHODS}

Brain slices. Experiments were performed on hippocampal CA3 neurons obtained from neonatal male Wistar rats, postnatal day (P) 2-4 (0 taken 
as the day of birth). Brains were removed from cryo-anesthetized rats and submerged in artificial CFS (ACSF) (in $\mathrm{mm}$ ): $\mathrm{NaCl} 126, \mathrm{KCl}$ 3.5, $\mathrm{CaCl}_{2} 2, \mathrm{MgCl}_{2} 1.3, \mathrm{NaH}_{2} \mathrm{PO}_{4} 1.2, \mathrm{NaHCO}_{3} 25$, and glucose 11, $\mathrm{pH}$ 7.4, when equilibrated with $95 \% \mathrm{O}_{2}$ and $5 \% \mathrm{CO}_{2}$. Hippocampal slices, $600 \mu \mathrm{M}$ thick, were cut with a McIlwain tissue chopper and incubated in $\mathrm{ACSF}$ at room temperature for at least $60 \mathrm{~min}$ before use. Individual slices were then transferred to a submerged recording chamber and superfused with $\mathrm{ACSF}$ at $2.5-3 \mathrm{ml} / \mathrm{min}$ at $34^{\circ} \mathrm{C}$.

To induce asynchronous quantal release of $\mathrm{GABA}, \mathrm{CaCl}_{2}(2 \mathrm{~mm})$ was substituted for $\mathrm{ACSF}$ to $\mathrm{SrCl}_{2}(4 \mathrm{mM})$, and $\mathrm{MgCl}_{2}$ was raised to $2 \mathrm{~mm}$ $\left(\mathrm{Sr}^{2+}-\mathrm{ACSF}\right)$. Miniature TTX-insensitive GABAergic events were measured in hypertonic solution $\left(\mathrm{Sr}^{2+}-\mathrm{ACSF}\right.$ complemented with $50 \mathrm{~mm}$ sucrose) to increase the frequency of events.

Whole-cell recordings. Whole-cell recordings were obtained using the "blind" patch-clamp technique. Recordings were performed with an Axopatch 200B (Axon Instruments, Foster City, CA) amplifier. Microelectrodes (4-8 M $\Omega$ ) were filled with an internal solution of the following composition (in mM): potassium gluconate $100, \mathrm{CaCl}_{2}$ 0.1, EGTA 1.1, HEPES 10, CsCl 20, MgATP 2, $\mathrm{MgCl}_{2}$ 5, cAMP 0.2, NaGTP 0.6, (triethylamino)- $N$-(2,6-dimethylphenyl) acetamine (QX314) 2, pH 7.25, 275 mOsm. During experiments, before each stimulation, series resistances, capacitance, and membrane resistance were determined by an on-line fitting analysis of the transient currents in response to a $5 \mathrm{mV}$ pulse with Acquis Software (ACQUIS, G. Sadoc, Biological, Orsay, France). Compensation parameters were set to 50-70\%. Cells recorded with unstable membrane resistance or series resistances were discarded.

Stimulation. Evoked postsynaptic potentials or currents were elicited by stimulation with a bipolar tungsten electrode, $50 \mu \mathrm{m}$ in diameter (30-60 $\mu \mathrm{sec} ; 10-30 \mathrm{~V}, 0.03 \mathrm{~Hz}$ ), located in the hilar side of the CA3 stratum radiatum. Tetanic stimuli (TS) $(100 \mathrm{~Hz}, 1 \mathrm{sec}$, three trains delivered at $30 \mathrm{sec}$ intervals) were applied via the same stimulating electrode. TS was applied between 10 and 12 min after breaking the seal. The intensity of test and tetanic stimuli was two to three times the threshold required to elicit $\mathrm{GABA}_{\mathrm{A}}$-mediated responses. In most experiments, a second stimulating electrode was placed in the stratum radiatum on the opposite side of the recording pipette. Independent fiber bundles named "test" and "control" pathways were then alternately activated. Tetanic stimulation was delivered only to the test pathway.

Data acquisition and analysis. Evoked $\mathrm{GABA}_{\mathrm{A}}$ EPSCs or $\mathrm{GABA}_{\mathrm{A}}$ EPSPs were recorded on line with an electrostatic recorder (Gould), simultaneously digitized, and stored on a personal computer or digital tape recorder (Biological) for subsequent analysis (ACQUIS, G. Sadoc, Biological). Spontaneous and miniature quantal $\mathrm{GABA}_{\mathrm{A}}$ EPSCs were detected semiautomatically with Acquis Software. The detection threshold was set at twice the baseline noise. The fact that no false events would be identified was confirmed by visual inspection for each experiment. To quantify the effect of TS on the frequency of $\mathrm{Sr}^{2+}$-induced asynchronous $\mathrm{GABA}_{\mathrm{A}}$ EPSCs, all events within a given time window were taken into account. To quantify the effect of TS on the amplitude of $\mathrm{GABA}_{\mathrm{A}}$ EPSCs, analysis was only performed on single isolated events within the same time window. Averaged cumulative histograms were obtained by normalizing each distribution to the corresponding median value ob-

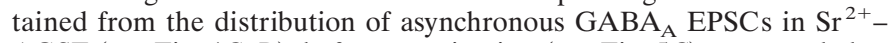
ACSF (see Fig. 4C-D), before tetanization (see Fig. $5 C$ ), or recorded at $-80 \mathrm{mV}$ (see Fig. $5 E$ ). In most experiments a control and a test pathway were monitored, and comparisons of the slope and amplitude of the test $\mathrm{GABA}_{\mathrm{A}}$-mediated responses were performed with the control pathway. The amplitude of the TS-induced current was measured at the peak of the response. For experiments in which TS was delivered at a depolarized potential, a holding potential of approximately $-25 \mathrm{mV}$ was chosen because it corresponds to the reversal potential of $\mathrm{GABA}_{\mathrm{A}}$ receptormediated currents with our recording solution. This procedure allowed us to measure the NMDA-mediated current induced by TS.

For data presented as the mean \pm SEM, statistical analysis was performed using a Student's paired $t$ test. When differences between two cumulative amplitude distributions were compared, the KolmogorovSmirnov was used. Statistical analysis of percent values was performed with ANOVA tests. Data were judged to differ when $p<0.05$.

Drugs. Bicuculline, 6-cyano-7-nitroquinoxaline-2,3-dione (CNQX), $\mathrm{D}(-)$ 2-amino-5-phosphovaleric acid (D-AP5), and QX314 were purchased from Tocris Cookson. Baclofen was purchased from Sigma (St. Louis, MO). Tetrodotoxin (TTX) was purchased from Latoxan. Baclofen, bicuculline, CNQX, D-AP5, and TTX were dissolved in ACSF and applied by bath while QX314 was dissolved in the intracellular pipette solution.

\section{RESULTS}

In P2-P4 CA3 pyramidal neurons, in the presence of ionotropic glutamate receptor antagonists $(10 \mu \mathrm{M}$ CNQX and $50 \mu \mathrm{M}$ D-AP5), stimulation of the afferent fibers evokes synaptic potentials mediated entirely by the activation of $\mathrm{GABA}_{\mathrm{A}}$ receptors. The GABAergic responses at this developmental stage are excitatory and can reach the threshold for action potential generation (Ben-Ari et al., 1989; Leinekugel et al., 1997). Hereafter they will therefore be referred to as $\mathrm{GABA}_{\mathrm{A}}$ EPSPs or GABA $\mathrm{A}_{\mathrm{A}}$ EPSCs. In a previous study (McLean et al., 1996) using intracellular recordings, we have reported that tetanic stimulations of GABAergic and glutamatergic fibers lead to a homosynaptic long-term depression of $\mathrm{GABA}_{\mathrm{A}}$ EPSPs $\left(\mathrm{LTD}_{\mathrm{GABA}-\mathrm{A}}\right)$ that is prevented by bath application of D-AP5 $(50 \mu \mathrm{M})$ or bicuculline $(10 \mu \mathrm{M})$.

Although these pharmacological procedures show that induction of $\mathrm{LTD}_{\mathrm{GABA}-\mathrm{A}}$ requires the activation of $\mathrm{GABA}_{\mathrm{A}}$ and NMDA receptors, they do not allow determination of the following: (1) whether postsynaptic voltage changes are required, (2) the location of the NMDA receptors involved in LTD $_{\mathrm{GABA}-\mathrm{A}}$ induction (i.e., on pyramidal cells or interneurons), and (3) the exact role of $\mathrm{GABA}_{\mathrm{A}}$ receptors. In the present study, to determine answers to these questions we performed whole-cell recordings to adequately clamp the voltage and apply the TS at different holding potentials.

\section{Postsynaptic induction of LTD GABA-A $_{\text {. }}$}

\section{$L T D_{G A B A-A}$ induction requires a membrane depolarization}

In a first set of experiments, we repeated the protocol used in our earlier study to test the effect of tetanic stimulations on $\mathrm{GABA}_{\mathrm{A}}$ EPSPs (Fig. 1A,B). (1) Two independent afferent pathways (control and test) were stimulated alternately to evoke monosynaptic $\mathrm{GABA}_{\mathrm{A}}$ EPSPs in the presence of CNQX $(10 \mu \mathrm{M})$ and D-AP5 $(50 \mu \mathrm{M}) ;(2)$ after a control period, D-AP5 was washed out. In this and subsequent experiments, D-AP5 was considered to be sufficiently washed out when evoked polysynaptic activities, termed Giant Depolarizing Potentials (GDPs), that required the activation of NMDA receptors could be recorded (Ben-Ari et al., 1989; McLean et al., 1995). (3) At the resting membrane potential of the cell, three tetanic stimulations $(100 \mathrm{~Hz}, 1 \mathrm{sec}$, three times, 30 sec interval) were delivered to the test pathway in the presence of CNQX $(10 \mu \mathrm{M})$. The TS induced an averaged membrane depolarization of $19 \pm 4 \mathrm{mV}(n=7)$ and a persistent (at least $40 \mathrm{~min}$ )

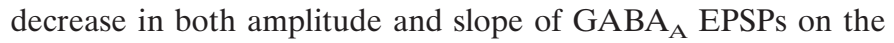
test but not the control pathway on reintroduction of D-AP5 (Fig. $1 A$ ). This phenomenon was observed in 7 of 10 pyramidal cells. On average, the slope of the test $\mathrm{GABA}_{\mathrm{A}}$ EPSPs was $49 \pm 9 \%$ of the control pathway $20 \mathrm{~min}$ after TS $(n=7 ; p<0.01)$ (Fig. $1 B)$.

Having established that LTD $_{\text {GABA-A }}$ can reliably be induced with whole-cell recordings, we examined whether a membrane depolarization during TS is required for the induction of LTD $_{\text {GABA-A }}$. To prevent the TS-induced membrane depolarization, the cells were voltage-clamped and TS was delivered at a holding potential of $-80 \mathrm{mV}$. In this condition, TS induced an inward current of $-446 \pm 88 \mathrm{pA}(n=7)$ but did not produce LTD $_{\text {GABA-A }}$ (Fig. $1 C, D$ ); the average amplitude of the test $\mathrm{GABA}_{\mathrm{A}}$ EPSCs was $99 \pm 11 \%$ of the control pathway $20 \mathrm{~min}$ after TS $(n=7 ; p=0.90)$. Therefore, LTD $_{\mathrm{GABA}-\mathrm{A}}$ induction requires a membrane depolarization. 
A Test pathway

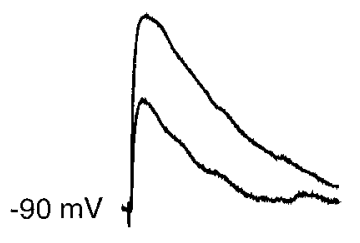

C

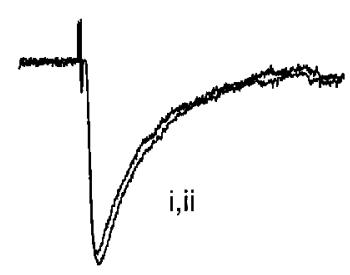

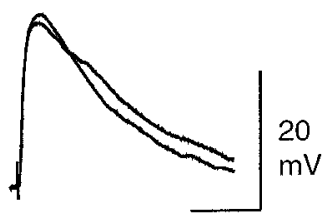

$100 \mathrm{~ms}$

$D$
Control pathway
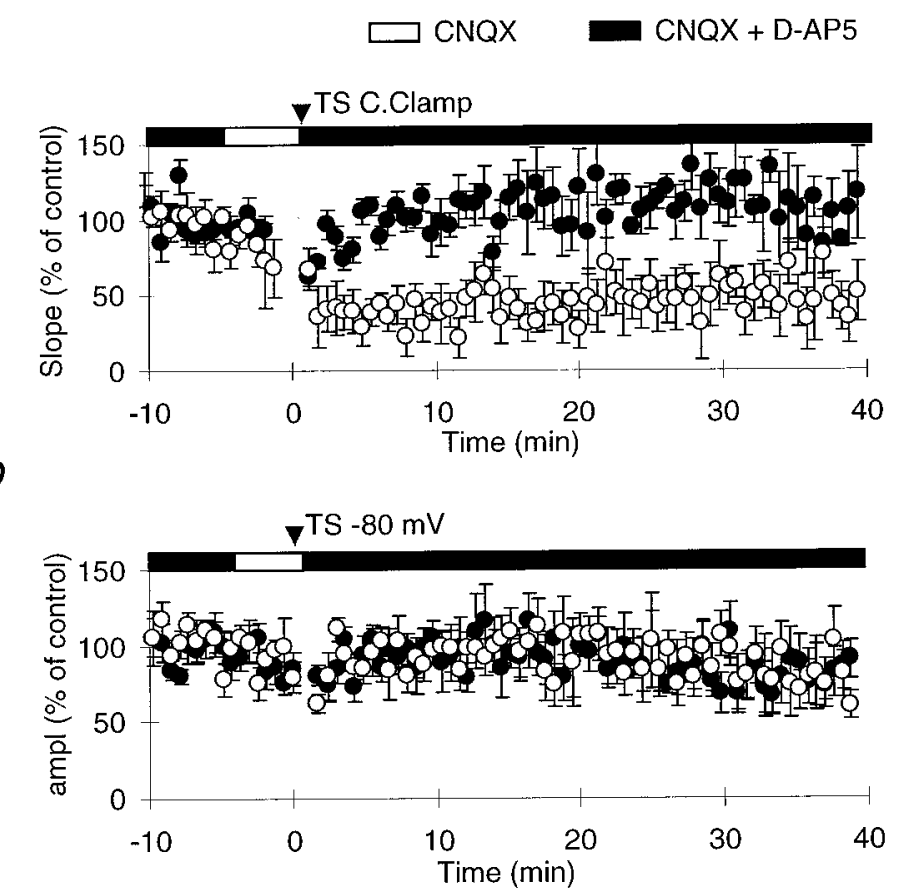

Figure 1. A postsynaptic depolarization is required for the induction of $\mathrm{LTD}_{\mathrm{GABA}-\mathrm{A}} \cdot A$, Superimposed averaged GABA $\mathrm{EPSPs}_{\mathrm{A}}$ recorded at $\mathrm{P} 3$ in CNQX $(10 \mu \mathrm{M})$ and D-AP5 $(50 \mu \mathrm{M})$ before $(i)$ and 20 min after $(i i)$ TS. TS was applied on the test pathway in the presence of CNQX (10 $\mu \mathrm{M})$. The left traces were obtained from the test pathway $(\bigcirc)$, and the right traces were obtained from the control pathway $(\bullet)$. $B$, Time course of changes in the $\mathrm{GABA}_{\mathrm{A}}$ EPSP slope presented as a percentage of pretetanized slope on the test $(\bigcirc)$ and the control $(\bullet)$ pathways $(n=7)$. In this and subsequent figures, unless otherwise indicated, all experiments were performed in CNQX $(10 \mu \mathrm{M})$ and D-AP5 $(50 \mu \mathrm{M})$ ( filled bar), except for the 5-10 min before TS during

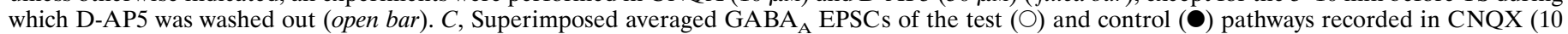
$\mu \mathrm{M})$ and D-AP5 $(50 \mu \mathrm{M})$ before $(i)$ and 20 min after (ii) TS. TS was given at a holding membrane potential of $-80 \mathrm{mV}$ in the presence of CNQX (10 $\mu \mathrm{M})$ alone. The amplitude of $\mathrm{GABA}_{\mathrm{A}}$-mediated EPSCs on the test pathway was not affected by TS, and the differences remained comparable to the control pathway. $D$, Average time course of changes in the $\mathrm{GABA}_{\mathrm{A}}$ EPSCs amplitude presented as a percentage of pretetanized amplitude on the test $(\bigcirc)$ and control $(\bullet)$ pathways $(n=7)$.

\section{$L T D_{G A B A-A}$ induction requires the activation of postsynaptic NMDA receptors}

We next determined whether the NMDA receptors involved in the induction of LTD $_{\text {GABA-A }}$ are localized at the postsynaptic level on the pyramidal cells. To investigate this point, the TS was delivered at a depolarized holding potential at which the blockade of NMDA channels by $\mathrm{Mg}^{2+}$ is alleviated (Nowak et al., 1984). When delivered at a holding potential of $-28 \pm 2 \mathrm{mV}(n=$ $10)$, TS produced an inward current of $-45 \pm 5 \mathrm{pA}(n=10)$ and induced a robust homosynaptic $\mathrm{LTD}_{\mathrm{GABA}-\mathrm{A}}($ Fig. $2 A, B)$ : the average amplitude of the test $\mathrm{GABA}_{\mathrm{A}}$ EPSCs was $54 \pm 8 \%$ of the control pathway 20 min after TS $(p<0.01 ; n=10)$. A transient depression of $\mathrm{GABA}_{\mathrm{A}}$ EPSCs was also observed on the control pathway. This depression was significant $2 \mathrm{~min}(69 \pm 6 \%$ of pre-tetanized level; $p<0.001 ; n=10$ ) but not 5 min after TS (89 $\pm 8 \% ; p=0.15 ; n=10)$. Application of D-AP5 during TS abolished the TS-induced inward current $(-3 \pm 3 \mathrm{pA}$ at $-26 \pm 1$ $\mathrm{mV}$ ) and prevented the induction of $\mathrm{LTD}_{\mathrm{GABA}-\mathrm{A}}$ (Fig. $2 C, D$ ): the average amplitude of the test $\mathrm{GABA}_{\mathrm{A}}$ EPSCs was $93 \pm 7 \%$ of control 20 min after TS ( $p=0.36 ; n=7)$. With the observation that TS fails to induce LTD $_{\mathrm{GABA}-\mathrm{A}}$ when delivered at a hyperpolarized holding potential (Fig. $1 C, D$ ), at which $\mathrm{Mg}^{2+}$ efficiently blocks postsynaptic NMDA channels (Nowak et al., 1984), these results demonstrate that $\mathrm{LTD}_{\mathrm{GABA}-\mathrm{A}}$ induction requires the activation of postsynaptic NMDA receptors.

\section{TD $D_{\text {GABA-A }}$ induction requires a $\mathrm{GABA}_{\mathrm{A}}$ receptor-mediated depolarization}

We further determined the exact role of $\mathrm{GABA}_{\mathrm{A}}$ receptors in the

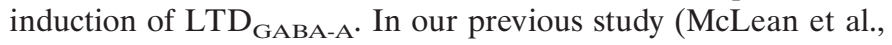
1996), application of bicuculline abolished the TS-induced membrane depolarization and prevented the induction of LTD $_{\text {GABA-A}}$, suggesting that the membrane depolarization required for $\mathrm{LTD}_{\mathrm{GABA}-\mathrm{A}}$ induction is provided by the activation of $\mathrm{GABA}_{\mathrm{A}}$ receptors. To exclude a direct role of $\mathrm{GABA}_{\mathrm{A}}$ receptors' activation, bicuculline was applied during TS while the cell was clamped at a depolarized holding potential $(-25 \mathrm{mV})$. In these conditions, the TS induced an inward current of $-70 \pm 16 \mathrm{pA}$

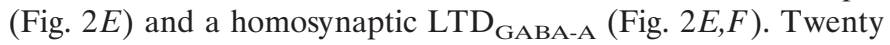
minutes after the washout of bicuculline, only the control $\mathrm{GABA}_{\mathrm{A}}$ EPSCs, but not the test GABA $_{\mathrm{A}}$ EPSCs, recovered to pretetanized values (Fig. $2 F$ ); the average amplitude of the test $\mathrm{GABA}_{\mathrm{A}}$ EPSCs was $59 \pm 8 \%$ of the control pathway 20 min after TS $(p<0.01 ; n=6)$ (Fig. $1 E, F)$. Therefore, $\mathrm{GABA}_{\mathrm{A}}$ receptormediated depolarization, and not the activation of $\mathrm{GABA}_{\mathrm{A}}$ receptors itself, is required for the induction of LTD $_{\mathrm{GABA}-\mathrm{A}}$.

Altogether these data demonstrate that the induction of LTD $_{\text {GABA-A }}$ required an initial membrane depolarization provided by depolarizing $\mathrm{GABA}_{\mathrm{A}}$ receptor-mediated conductances that is necessary for the removal of $\mathrm{Mg}^{2+}$ block of NMDA channels. 


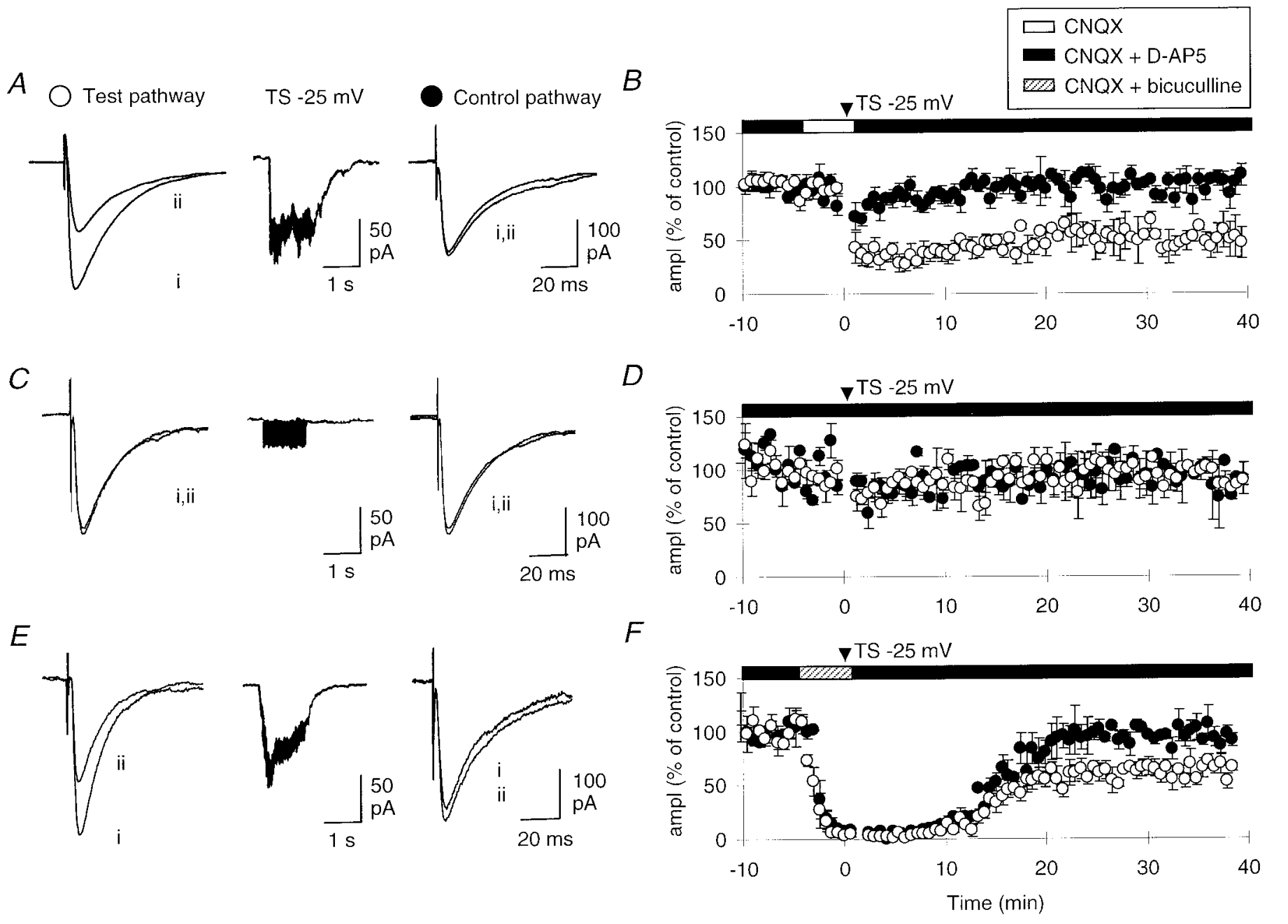

Figure 2. Synergistic activation of postsynaptic NMDA and GABA $\mathrm{A}_{\mathrm{A}}$ receptors is required for the induction of $\mathrm{LTD}_{\mathrm{GABA}-\mathrm{A}} \cdot A$, Superimposed averaged $\mathrm{GABA}_{\mathrm{A}}$ EPSCs of the test $(\bigcirc)$ and control $(\bullet)$ pathways recorded in CNQX $(10 \mu \mathrm{M})$ and D-AP5 $(50 \mu \mathrm{M})$ before $(i)$ and 20 min after TS $(i i)$. TS was given at a depolarized membrane potential (approximately $-25 \mathrm{mV}$; middle trace). After TS, there was a clear decrease in the amplitude of the test

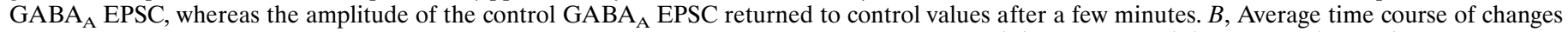

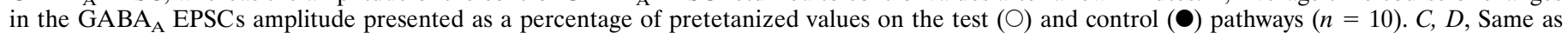

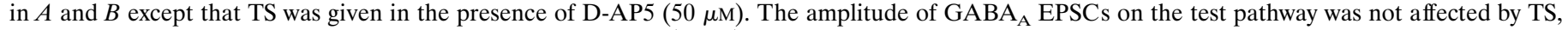
and the differences remained comparable to the control pathway $(n=7) . E, F$, Same as in $A$ and $B$ except that TS was given in the presence of bicuculline

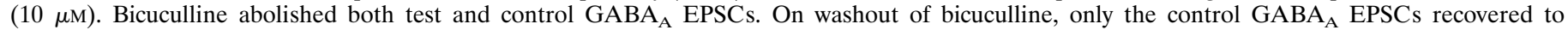
pretetanized values $(n=6) . B, D, F, \mathrm{CNQX}$, open bar; CNQX + D-AP5, filled bar; CNQX + bicuculline, dashed bar.

\section{Presynaptic expression of LTD $\mathrm{GABA}_{\mathrm{GA}}$}

We next attempted to determine the locus of LTD $_{\mathrm{GABA}-\mathrm{A}}$ expression. To distinguish between presynaptic and postsynaptic expression we used two different experimental paradigms.

\section{Increase in variability of the $G A B A_{A}$ EPSC amplitudes}

Analysis of the $\mathrm{CV}$ of synaptic responses can be used to distinguish between presynaptic and postsynaptic sites of changes in synaptic strength (Faber and Korn, 1991; Manabe et al., 1993; Alger et al., 1996). In accordance with a simple binomial distribution, the CV should be independent of quantal size. Therefore, a change in the $\mathrm{CV}$ suggests a presynaptic site, whereas no change suggests a postsynaptic site. We first tested the validity of the technique in our experimental conditions by modifying the quantal content with baclofen (Thompson and Gähwiler, 1992) and the quantal size with bicuculline. A decrease in the quantal content induced by the activation of presynaptic $\mathrm{GABA}_{\mathrm{B}}$ receptors with baclofen $(1 \mu \mathrm{M})$ reduced the amplitude of $\mathrm{GABA}_{\mathrm{A}}$
EPSCs $\left(53 \pm 5 \%\right.$ of control values) and increased the $\mathrm{CV}^{2}$ by $322 \pm 29 \%(p<0.01 ; n=7)$ (Fig. $3 A)$. In contrast, a reduction in the number of available postsynaptic $\mathrm{GABA}_{\mathrm{A}}$ receptors with a nonsaturating concentration of bicuculline $(1 \mu \mathrm{M})$ led to a similar decrease of the amplitude of $\mathrm{GABA}_{\mathrm{A}}$ EPSCs $(44 \pm 5 \%$ of control), but the $\mathrm{CV}^{2}$ was not affected $(93 \pm 8 \% ; p=0.52 ; n=$ 8) (Fig. 3B). Having established the validity of the technique, we investigated the effect of $\mathrm{LTD}_{\mathrm{GABA}-\mathrm{A}}$ induction on the $\mathrm{CV}^{2}$ of the evoked $\mathrm{GABA}_{\mathrm{A}}$ EPSCs. Twenty minutes after the induction of LTD $_{\mathrm{GABA}-\mathrm{A}}$, the amplitude of the test $\mathrm{GABA}_{\mathrm{A}}$ EPSCs was reduced to $48 \pm 6 \%$ of control, and the $\mathrm{CV}^{2}$ was increased to $274 \pm 16 \%(p<0.01 ; n=10)$ (Fig. 3C). On the control pathway, the amplitude and $\mathrm{CV}^{2}$ remained constant $(102 \pm 6 \%, p=0.84$; $91 \pm 8 \%, p=0.44$, respectively; $n=10$ ).

In Figure $3 D$, the ratio of $\mathrm{CV}^{2}$ in control and during application of agonists or after TS is plotted versus the ratio of the mean test GABA $\mathrm{A}_{\mathrm{A}}$ EPSC amplitude (EPSC $\left.\mathrm{test}_{\mathrm{t}}\right)$ and control $\left(\mathrm{EPSC}_{\mathrm{ctrr}}\right)$ for each experiment. Most ( 8 of 10 cells) of the points obtained 

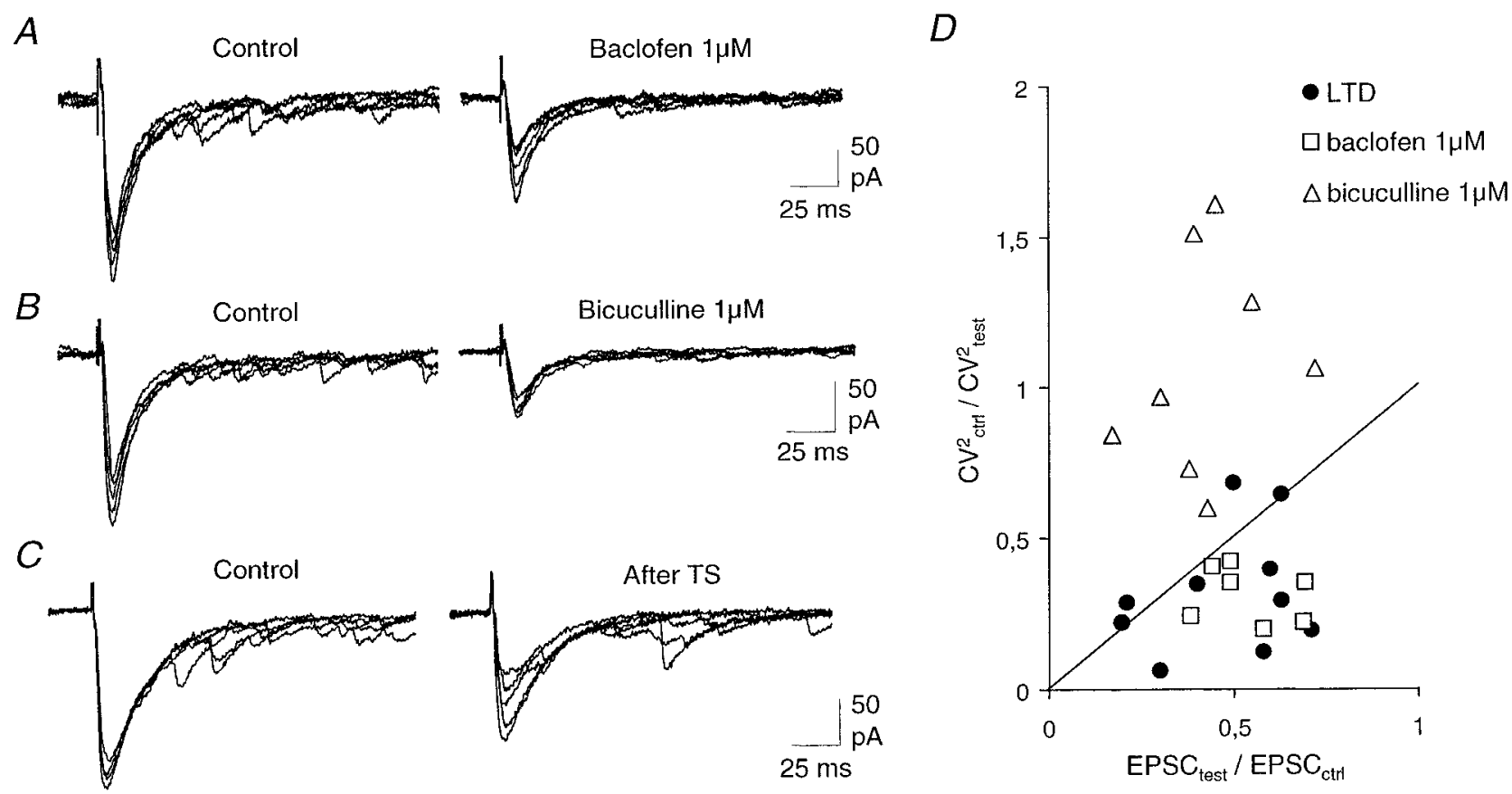

Figure 3. Increase in the variability of the GABA EPSCs after LTD $_{\mathrm{GABA}-\mathrm{A}} \cdot A$, Superimposed GABA $\mathrm{APSCs}_{\mathrm{A}}$ recorded in CNQX $(10 \mu \mathrm{M})$ and D-AP5 $(50 \mu \mathrm{M})$ before (left traces) and during (right traces) application of baclofen $(1 \mu \mathrm{M})$. Baclofen induced a reduction in the amplitude of the GABA EPSCs and an increase in the coefficient of variation of the amplitude. $B$, Same as in $A$ except that bicuculline $(1 \mu \mathrm{M})$ was applied instead of baclofen. Bicuculline

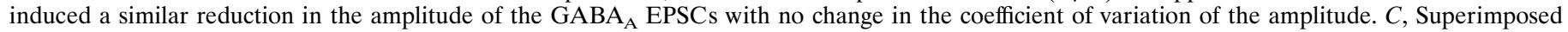
GABA $_{\mathrm{A}}$ EPSCs recorded in CNQX $(10 \mu \mathrm{M})$ and D-AP5 $(50 \mu \mathrm{M})$ before (left traces) and 20 min after (right traces) the induction of LTD ${ }_{\mathrm{GABA}-\mathrm{A}}\left(\mathbf{O}_{)}\right.$.

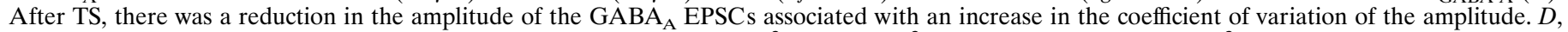
Summary graph of all the experiments. The graph shows the ratio of $\mathrm{CV}^{2}$ before $\left(\mathrm{CV}^{2}{ }_{\text {ctrl }}\right)$ and after treatment $\left(\mathrm{CV}^{2}\right.$ test $)$, plotted against the ratio of the mean EPSC amplitudes after pharmacological treatment or LTD (EPSC $\left.\mathrm{test}_{\mathrm{EPSC}} / \mathrm{EPrl}_{\mathrm{c}}\right)$. Each point represents a single experiment in baclofen $(1 \mu \mathrm{M}$, $\square)$, in bicuculline $(1 \mu \mathrm{M}, \triangle)$, or $20 \mathrm{~min}$ after induction of $\operatorname{LTD}_{\mathrm{GABA}-\mathrm{A}}(\bullet)$.

from experiments in which LTD $_{\mathrm{GABA}-\mathrm{A}}$ was induced (Fig. $3 D$, -) and those obtained from baclofen experiments $(\square)$ were clustered on the same region of the graph and separated from those obtained from bicuculline experiments $(\triangle)$. These data are consistent with a presynaptic locus for the expression of LTD $_{\text {GABA-A }}$.

\section{Reduction of the frequency of quantal $G A B A_{A} E P S C s$}

To further study the locus of LTD $_{\mathrm{GABA}-\mathrm{A}}$ expression, we examined the effects of LTD on the size and frequency of quantal $\mathrm{GABA}_{\mathrm{A}}$ events generated by asynchronous release in $\mathrm{Sr}^{2+}$ (Miledi, 1966). Because asynchronous release can occur at the subset of synapses that are stimulated, this allows a detailed analysis of quantal events originating from these synapses (Oliet et al., 1996, 1997; Morishita and Alger, 1997; Rumpel and Behrends, 1999).

Two control experiments were performed to show that in our experimental conditions the asynchronous events evoked in the presence of $\mathrm{Sr}^{2+}$ are generated by the stimulated GABAergic fibers and represent quantal events. We first compared the background and poststimulus frequency of $\mathrm{GABA}_{\mathrm{A}}$ EPSCs occurring during a $500 \mathrm{msec}$ time window before and $200 \mathrm{msec}$ after the stimulus artifact. An example of such an experiment is shown in Figure $4 A, B$. In $\mathrm{Ca}^{2+}-\mathrm{ACSF}$, the poststimulus and background frequencies of $\mathrm{GABA}_{\mathrm{A}}$ EPSCs were comparable $(16.1 \pm 2.5$ vs $18.1 \pm 0.9 \mathrm{~Hz} ; p=0.31)$ (Fig. $4 B)$. In contrast, 5-10 min after perfusion with $\mathrm{Sr}^{2+}-\mathrm{ACSF}$, which led to a reduction of the evoked $\mathrm{GABA}_{\mathrm{A}}$ EPSCs amplitude (from $-289 \pm 15$ to $-79 \pm 8 \mathrm{pA} ; p<0.001)($ Fig. $4 A$ ), the poststimu- lus frequency of $\mathrm{GABA}_{\mathrm{A}}$ EPSCs significantly increased in comparison to the background frequency $(13.6 \pm 1.6$ vs $7.8 \pm$ $0.6 \mathrm{~Hz} ; p<0.001$ ) (Fig. $4 A, B$ ). Therefore, most events detected after the stimulation were indeed evoked asynchronous $\mathrm{GABA}_{\mathrm{A}}$ EPSCs.

We also observed a significant and stable decrease in the amplitude of the $\mathrm{GABA}_{\mathrm{A}}$ EPSCs occurring during the poststimulus analysis. For the cell depicted in Figure $4 A, B$, the mean amplitude of $\mathrm{GABA}_{\mathrm{A}}$ EPSCs decreased from $-29 \pm 2 \mathrm{pA}$ in $\mathrm{Ca}^{2+}-\mathrm{ACSF}$ to $-15 \pm 1 \mathrm{pA}(p<0.001) 10$ min after perfusion with $\mathrm{Sr}^{2+}-\mathrm{ACSF}$ and remained constant at $-14 \pm 1 \mathrm{pA}(p=$ 0.35) 10 min later. The reduction in the amplitude of $\mathrm{GABA}_{\mathrm{A}}$ EPSCs was further demonstrated by the shift to the left of the normalized cumulative amplitude distribution (Fig. $4 C)(n=4$; $p<0.005)$. We then compared the amplitude of the evoked asynchronous GABA $_{\mathrm{A}}$ EPSCs that occurred during the same 500 msec time window after the stimulation with the amplitude of spontaneous TTX-insensitive miniature $\mathrm{GABA}_{\mathrm{A}}$ EPSCs recorded in hypertonic $\mathrm{Sr}^{2+}-\mathrm{ACSF}$ (mGABA $\mathrm{m}_{\mathrm{A}}$ EPSCs). The amplitude distributions of evoked asynchronous GABA $_{\mathrm{A}}$ EPSCs were similar to those of $\mathrm{mGABA}_{\mathrm{A}}$ EPSCs (Fig. $\left.4 D\right)(p=0.28$; $n=5)$, indicating that they were quantal events.

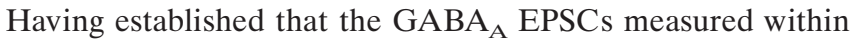
the $500 \mathrm{msec}$ time window taken $200 \mathrm{msec}$ after the stimulus artifact are evoked quantal events, we compared the amplitude and frequency of the evoked asynchronous GABA $_{\mathrm{A}}$ EPSCs before and after the induction of LTD $_{\text {GABA-A }}$ (Fig. $5 A$ ). After a control period during which asynchronous GABA $_{\mathrm{A}}$ EPSCs were 
$A$

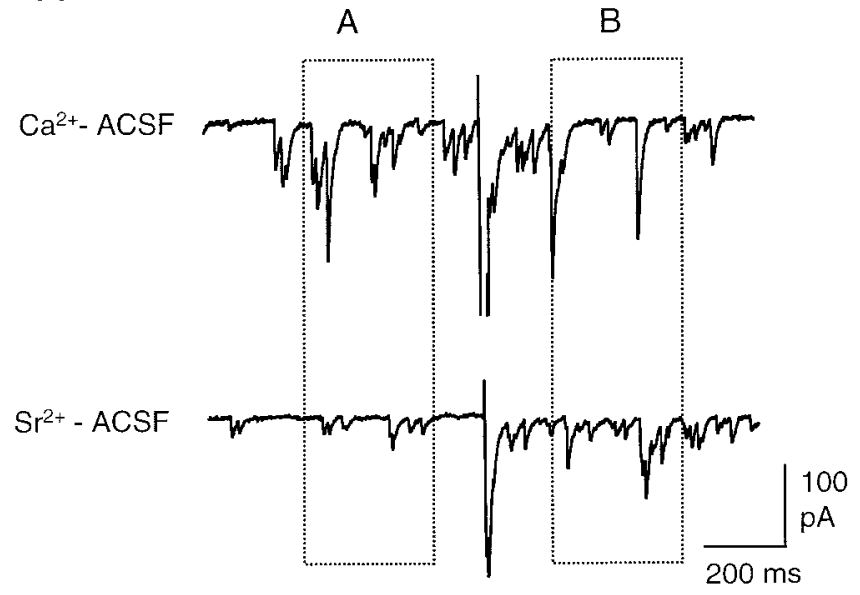

C

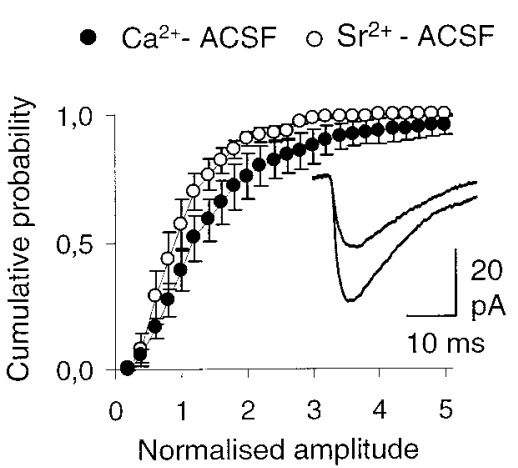

$B$

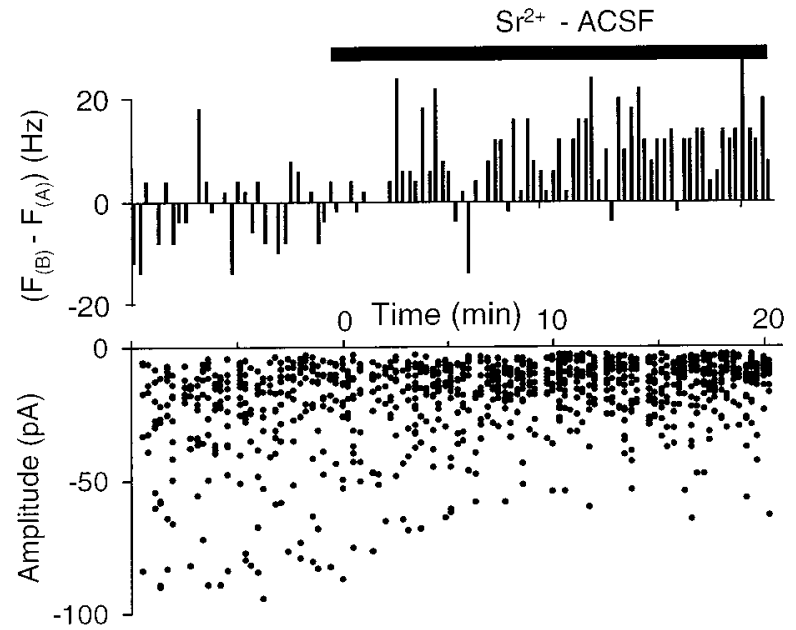

$D$

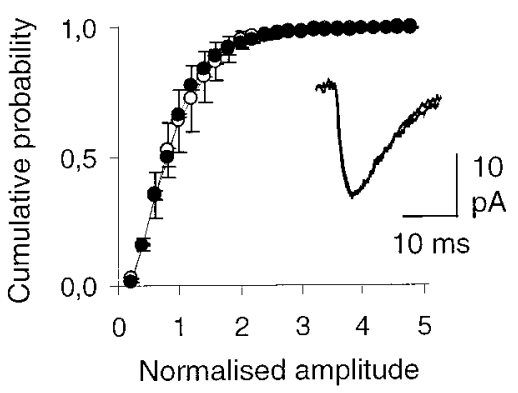

Figure 4. The asynchronous GABA EPSCs generated in the presence of $\mathrm{Sr}^{2+}$ are evoked quantal events. $A$, Representative traces of evoked $\mathrm{GABA}_{\mathrm{A}}$ EPSCs recorded in the presence of $\mathrm{Ca}^{2+}\left(\mathrm{Ca}^{2+}-A C S F\right)$ or $\mathrm{Sr}^{2+}\left(\mathrm{Sr}^{2+}-A C S F\right)$ in the presence of CNQX (10 $\left.\mu \mathrm{M}\right)$ and D-AP5 $(50 \mu \mathrm{M})$. A $500 \mathrm{msec}$ time window before and $200 \mathrm{msec}$ after the stimulus artifact was used to measured, respectively, the background and poststimulus frequency and amplitude of the $\mathrm{GABA}_{\mathrm{A}}$ EPSCs. $B$, Times course change in the frequency (top graph) and amplitude (bottom graph) of GABA EPSCs for the cell depicted in $A$. The variation in frequency is illustrated as the difference between the poststimulus frequency $\left(F_{(B)}\right)$ and the

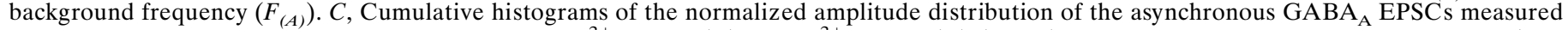
during the poststimulus $500 \mathrm{msec}$ time window in $\mathrm{Ca}^{2+}-\mathrm{ACSF}(O)$ and $\mathrm{Sr}^{2+}-\operatorname{ACSF}(\bullet)(n=5)$. The insets show superimposed averaged $(n=$ 20) $\mathrm{GABA}_{\mathrm{A}}$ EPSCs for one experiment under each set of conditions. $D$, Cumulative histograms of the normalized amplitude distribution of the

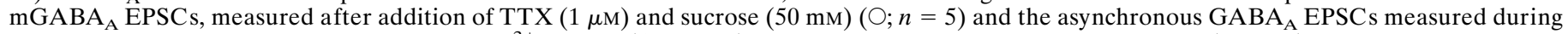
the poststimulus $500 \mathrm{msec}$ time window in $\operatorname{Sr}^{2+}-\operatorname{ACSF}(\boldsymbol{\bullet} ; n=5)$. The insets show superimposed averaged $(n=20)$ quantal events for one experiment under each set of conditions.

recorded in CNQX $(10 \mu \mathrm{M})$ and D-AP5 $(50 \mu \mathrm{M})$, the bathing solution was replaced by $\mathrm{Ca}^{2+}-\mathrm{ACSF}$ supplemented with CNQX $(10 \mu \mathrm{M})$. The frequency of evoked asynchronous GABA EPSCs $_{\mathrm{A}}$ first decreased (Fig. $5 B$ ) as the evoked responses became rapidly synchronous after the substitution of $\mathrm{Sr}^{2+}$ by $\mathrm{Ca}^{2+}$. The frequency of $\mathrm{GABA}_{\mathrm{A}}$ EPSCs then increased (Fig. 5B) as the polysynaptic activity recovered after the washout of D-AP5 (BenAri et al., 1989).

After washout of $\mathrm{Sr}^{2+}$, TS was applied at a depolarized holding potential $(-28 \pm 1 \mathrm{mV})$, and the $\mathrm{Ca}^{2+}-\mathrm{ACSF}$ was replaced by $\mathrm{Sr}^{2+}-\mathrm{ACSF}$ containing CNQX $(10 \mu \mathrm{M})$ and D-AP5 $(50 \mu \mathrm{M})$. After TS, the frequency of evoked asynchronous GABA EPSCs $_{\mathrm{A}}$ was reduced for at least $40 \mathrm{~min}$ to $61.2 \pm 4.0 \%$ of the pre-TS values (Fig. $5 B, D)(p<0.01 ; n=6)$. In contrast, the amplitude of evoked asynchronous GABA $_{\mathrm{A}}$ EPSCs after TS was not different from pretetanized values, as illustrated by the normalized cumulative amplitude distributions obtained before and $20 \mathrm{~min}$ after TS (Fig. $5 C$ ) $(p=0.61 ; n=6)$; the average amplitude of evoked asynchronous $\mathrm{GABA}_{\mathrm{A}}$ EPSCs after TS was $94.2 \pm 6.1 \%$ of the pretetanized values (Fig. $5 D)(p=0.36 ; n=6)$. In control experiments, long-term recordings (up to $1 \mathrm{hr}$ ) in $\mathrm{Sr}^{2+}-\mathrm{ACSF}$ altered neither the frequency (Fig. $5 B)(n=8)$ nor the amplitude

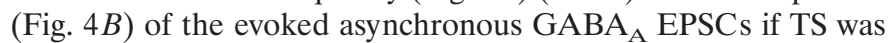
not delivered. These data therefore show that the decrease in the frequency observed after TS is not caused by a rundown of $\mathrm{GABA}_{\mathrm{A}}$ receptor-mediated responses.

The finding that $\mathrm{LTD}_{\mathrm{GABA}-\mathrm{A}}$ results from a reduction in quantal content and not quantal size further supports a presynaptic locus of expression. However, a decrease in the frequency of evoked asynchronous GABA $_{\mathrm{A}}$ EPSCs after TS may have arisen from a decrease in their amplitude below the detection threshold. To investigate this point, evoked asynchronous GABA $_{\mathrm{A}}$ EPSCs were recorded at two different holding potentials. As illustrated in Figure $5 E, F$, changing the holding potential from $-80 \mathrm{mV}$ to -60 $\mathrm{mV}$ resulted in a $23.7 \pm 3.5 \%$ decrease in the mean amplitude of evoked asynchronous $\mathrm{GABA}_{\mathrm{A}}$ EPSCs $(p<0.01 ; n=6)$. This decrease in the amplitude of evoked asynchronous $\mathrm{GABA}_{\mathrm{A}}$ EPSCs was not associated with a significant change in their 
A

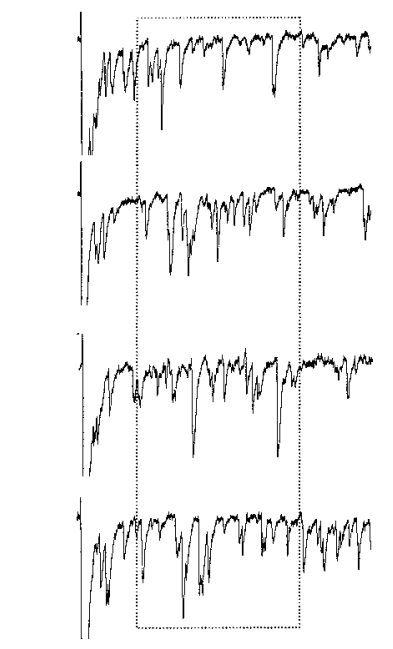

C

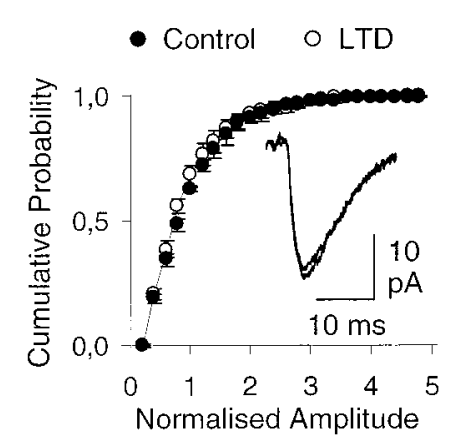

LTD

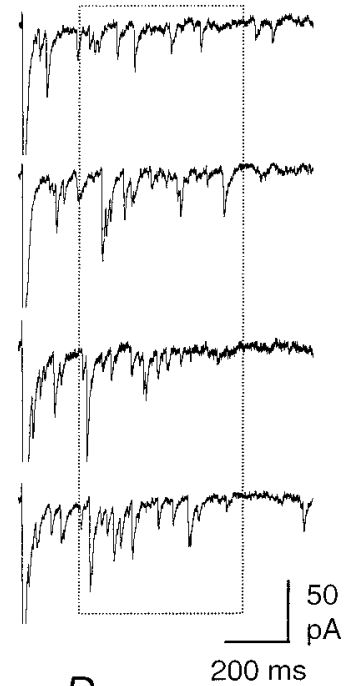

$D$

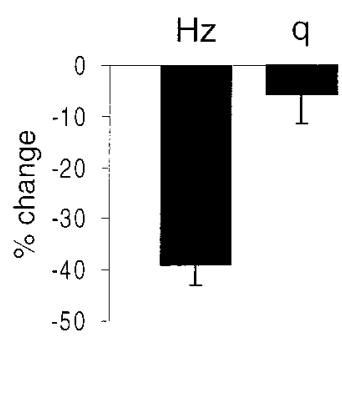

B

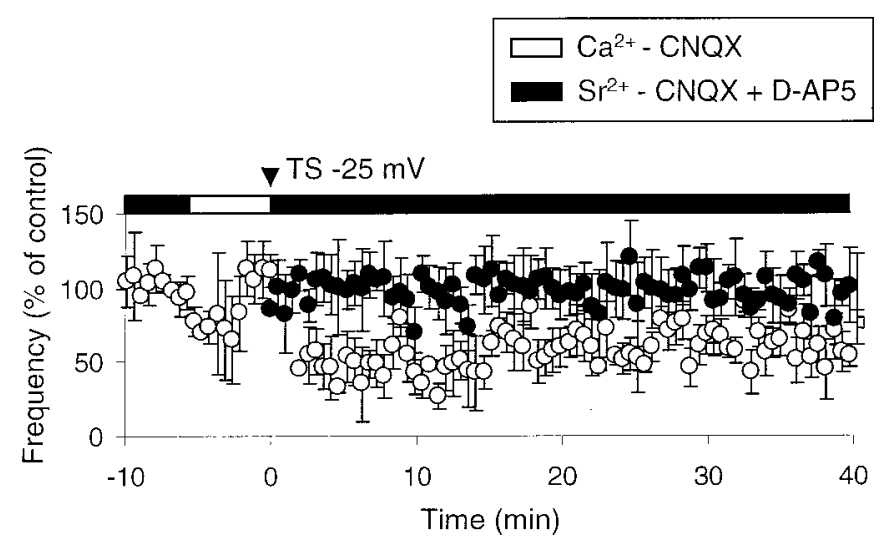

$E$

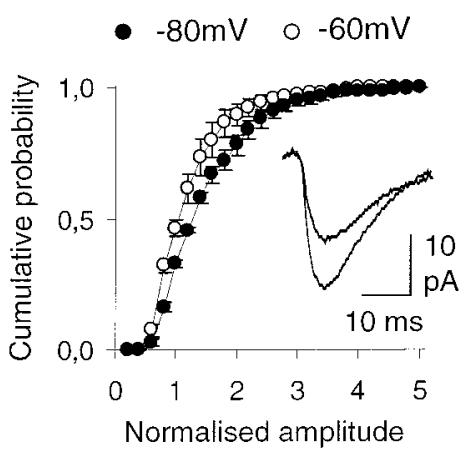

F

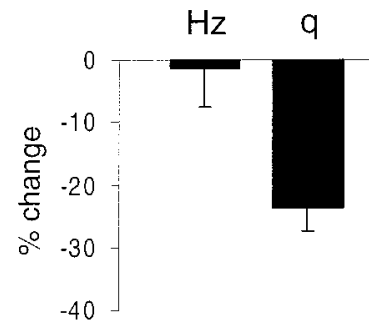

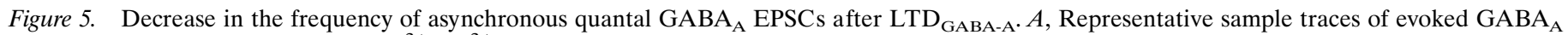
EPSCs recorded in the presence of $\mathrm{Sr}^{2+}\left(\mathrm{Sr}^{2+}-\mathrm{ACSF}\right)$, CNQX $(10 \mu \mathrm{M})$, and D-AP5 $(50 \mu \mathrm{M})$ before (Control, left traces) and 20 min after (LTD, right traces) TS. TS was applied in control ACSF and CNQX $(10 \mu \mathrm{M})$ at a depolarized membrane potential (approximately $-25 \mathrm{mV}) . B$, Average time course

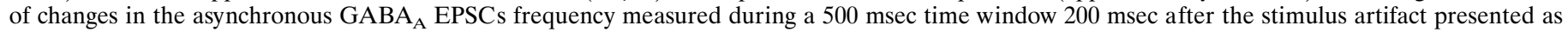
a percentage of control (pre-TS) frequency $(\bigcirc ; n=6)$. On the same graph is represented the time course of changes in the asynchronous GABA EPSCs frequency measured during the same time window obtained from long-term recordings in which TS was not delivered $(\mathbf{Q} ; n=8)$. $C$, Cumulative histograms of the normalized distribution of the asynchronous $\mathrm{GABA}_{\mathrm{A}}$ EPSCs amplitude measured in $\mathrm{Sr}^{2+}-\mathrm{ACSF}$ before $(O)$ and after $(\bullet)$ LTD $(n=$ $6)$. The insets show superimposed averaged $(n=20)$ quantal events for one experiment under each set of conditions. $D$, Average histograms of variations

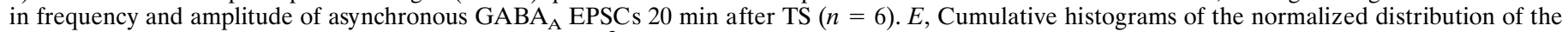

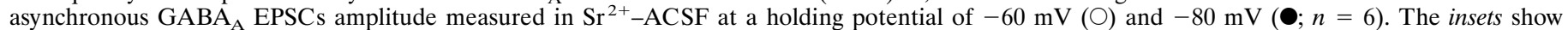

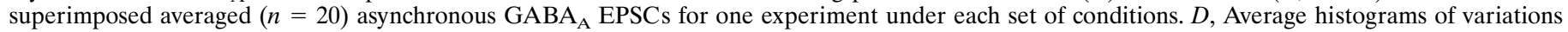
in frequency and amplitude of asynchronous $\mathrm{GABA}_{\mathrm{A}}$ EPSCs 20 min after TS $(n=6)$.

frequency $(1.4 \pm 6.1 \%$ decrease; $p=0.82 ; n=6)($ Fig. $5 F)$. These data therefore suggest that the TS-induced decrease in the frequency of evoked asynchronous $\mathrm{GABA}_{\mathrm{A}}$ EPSCs is likely attributable to a reduction in the number of events rather than to a decrease in their amplitude below the detection threshold.

\section{DISCUSSION}

\section{$\mathrm{GABA}_{A}$ and NMDA receptors act in synergy to induce LTD GABA-A}

Our conclusion that the induction of $\mathrm{LTD}_{\mathrm{GABA}-\mathrm{A}}$ requires the synergistic activation of postsynaptic $\mathrm{GABA}_{\mathrm{A}}$ and NMDA receptors under normal conditions is based on the following observations. First, LTD $_{\mathrm{GABA}-\mathrm{A}}$ was prevented when the cell was held at a hyperpolarized potential during TS, showing that a postsynaptic membrane depolarization is necessary. Second, bicuculline completely blocked the TS-induced depolarization and prevented the induction of LTD $_{\mathrm{GABA}-\mathrm{A}}$ when TS was delivered under current clamp mode at the resting membrane potential (McLean et al., 1996) but had no effect on LTD $_{\text {GABA-A }}$ induction when TS was delivered under voltage-clamp mode at a depolarized potential. These observations show that the only requirement for the activation of $\mathrm{GABA}_{\mathrm{A}}$ receptors is to provide the membrane depolarization necessary for LTD $_{\text {GABA-A }}$ induction. Third, when the recorded cell was held at a depolarized potential, TS produced an inward current blocked by D-AP5 and induced an NMDAdependent $\mathrm{LTD}_{\mathrm{GABA}-\mathrm{A}}$. Therefore, the NMDA receptors involved in the induction of LTD $_{\mathrm{GABA}-\mathrm{A}}$ are located on the postsynaptic pyramidal neurons.

The mechanism of $\mathrm{LTD}_{\mathrm{GABA}-\mathrm{A}}$ induction is the following. During the first days of postnatal life, when GABA provides most of the excitatory drive in neonatal rat hippocampus (Ben-Ari et al., 1989), GABA released during TS produces a depolarization via the activation of $\mathrm{GABA}_{\mathrm{A}}$ receptors. This depolarization is 
strong enough to remove the magnesium block from NMDA receptor-gated channels, activation of which is likely attributable to glutamate released during TS. Which glutamatergic fibers were activated during TS is presently unknown, but commissural, entorhinal, and mossy fibers are all present in the neonatal hippocampus (Amaral and Dent, 1981; Super and Soriano, 1994). The co-activation of $\mathrm{GABA}_{\mathrm{A}}$ and NMDA receptors leads to a long-term depression in the efficacy of GABAergic synaptic transmission. LTD $_{\text {GABA-A }}$ described in the present study is therefore unique in that its induction requires the activation of $\mathrm{GABA}_{\mathrm{A}}$ receptors, in contrast to the adult situation where a blockade of $\mathrm{GABA}_{\mathrm{A}}$ receptors (Komatsu and Iwakiri, 1993) or the activation of AMPA receptors (Stelzer et al., 1987) is required for the induction of NMDA receptor-dependent LTD of inhibitory GABAergic synaptic transmission.

As with most forms of synaptic plasticity, the induction of $\mathrm{LTD}_{\mathrm{GABA}-\mathrm{A}}$ in neonates requires a postsynaptic rise in $\left[\mathrm{Ca}^{2+}\right]_{\mathrm{i}}$ because LTD $_{\text {GABA-A }}$ was blocked by buffering postsynaptic calcium (McLean et al., 1996). A postsynaptic rise in $\left[\mathrm{Ca}^{2+}\right]_{\mathrm{i}}$ can be produced by the calcium entry via NMDA channels or voltagegated calcium channels (VDCCs), or by the release of calcium from internal calcium stores. Calcium entry through postsynaptic NMDA channels but not VDCCs is, at least in part, the likely mechanism by which change in postsynaptic $\left[\mathrm{Ca}^{2+}\right]_{\mathrm{i}}$ occurs. In a recent study (Caillard et al., 1999), we showed that an influx of calcium through VDCCs leads to an LTP of GABA receptormediated EPSCs in neonatal rat hippocampus. In the present

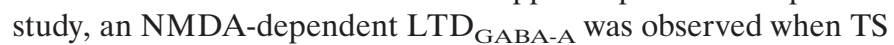
was applied at a depolarized holding potential (approximately $-25 \mathrm{mV}$ ). At this depolarized potential, the $\mathrm{Mg}^{2+}$ block of NMDA channels is removed (TS induces a D-AP5-sensitive inward current), and the VDCCs are largely inactivated (Mogul and Fox, 1991; Thompson and Wong, 1991). This observation only applies for voltage-clamp experiments; therefore, we cannot exclude a possible contribution of the VDCCs to the calcium influx when TS was applied under current-clamp mode. The role of internal calcium stores has not been investigated in the present study. However, their possible contribution, as reported in the plasticity of glutamatergic synaptic transmission (Reyes and Stanton, 1996), cannot be excluded. Further experiments will be required to determine the precise source and location of the calcium rise leading to the long-term depression of GABAergic synaptic transmission.

\section{LTD $_{\text {GABA-A }}$ is expressed presynaptically as a decrease in the probability of GABA release}

One of the main questions when studying long-term changes in the strength of synaptic efficacy concerns the locus of expression of such changes. Synaptic plasticity can be expressed either presynaptically as a modification in quantal content or postsynaptically as a modification in quantal size. LTP of inhibitory GABAergic synaptic transmission in adult hippocampus (Nusser et al., 1998) or cerebellum (Kano et al., 1992; Kano, 1996) is likely mediated by an upregulation in the sensitivity or number of postsynaptic $\mathrm{GABA}_{\mathrm{A}}$ receptors at functional synapses leading to an increase in quantal size. In contrast, in Mauthner cells, the expression of LTP at glycinergic synapses seems to be associated with the functional appearance of "presynaptically" latent inhibitory connections (Charpier et al., 1995; Oda et al., 1995). In keeping with a presynaptic mechanism, after a postsynaptic rise in $\left[\mathrm{Ca}^{2+}\right]_{\mathrm{i}}$ induced by the activation of VD$\mathrm{CCs}$, a short-lasting retrograde inhibitory control of GABA release, termed depolarization-induced suppression of inhibition, has been demonstrated in adult rat hippocampus (Alger et al., 1996; Morishita and Alger, 1997) and cerebellum (Glitsch et al., 1996).

Two lines of evidence indicate that LTD $_{\text {GABA-A }}$ is likely expressed as a presynaptic reduction in quantal content. First, LTD $_{\mathrm{GABA}-\mathrm{A}}$ is associated with an increase in the CV of $\mathrm{GABA}_{\mathrm{A}}$ EPSCs. According to a simple binomial distribution, the CV depends only on the number of releasing sites or the probability of release (Faber and Korn, 1991). Therefore changes in this parameter are interpreted as modifications in presynaptic function. By using control experiments to validate this method, we found that a decrease in the quantal content with baclofen, but not a decrease of quantal size with bicuculline, induced an increase in the CV of GABAergic postsynaptic currents. The second line of evidence in favor of the presynaptic hypothesis stems from the analysis of asynchronous evoked $\mathrm{GABA}_{\mathrm{A}}$ EPSCs recorded in the presence of $\mathrm{Sr}^{2+}$. After induction of $\mathrm{LTD}_{\mathrm{GABA}-\mathrm{A}}$, these events were reduced in number but not in size. In keeping with a recent study (Morishita and Alger, 1997), we report that these asynchronous events were indistinguishable in size from the miniature $\mathrm{GABA}_{\mathrm{A}}$ EPSCs. They are thus quantal events. We therefore conclude that $\mathrm{LTD}_{\mathrm{GABA}-\mathrm{A}}$ is associated with a decrease in the frequency of quantal events with no change in the quantal size.

The above results, namely an increase in the $\mathrm{CV}$ of evoked $\mathrm{GABA}_{\mathrm{A}}$ EPSCs and a decrease in the frequency of quantal events, are consistent with a reduction in the quantal content, i.e., the number of releasing sites or the probability of GABA release, during the expression of $\mathrm{LTD}_{\mathrm{GABA}-\mathrm{A}}$. If the expression of $\mathrm{LTD}_{\mathrm{GABA}-\mathrm{A}}$ is presynaptic whereas the induction requires postsynaptic processes, one would expect that a signal from pyramidal cells is transmitted back to the GABAergic terminals. The putative retrograde messenger involved is presently unknown, but the activation of NMDA receptors appears to be sufficient for its generation, whereas activation of $\mathrm{GABA}_{\mathrm{A}}$ receptors is not required because $\mathrm{LTD}_{\mathrm{GABA}-\mathrm{A}}$ could be induced in the presence of bicuculline.

Although extremely controversial with regard to glutamatergic synaptic transmission (Bear and Malenka, 1994; Manabe and Nicoll, 1994), a short-lasting retrograde control of GABA release has been clearly demonstrated in the cerebellum (Llano et al., 1991) and the hippocampus (Alger et al., 1996), with glutamate as the likely candidate underlying the retrograde signaling from postsynaptic cell to presynaptic GABAergic terminals (Glitsch et al., 1996; Morishita et al., 1998). An alternative possibility that cannot be completely excluded is that expression of LTD $_{\mathrm{GABA}-\mathrm{A}}$ is associated with an all-or-none downregulation of $\mathrm{GABA}_{\mathrm{A}}$ receptors at individual synapses, as opposed to the mechanism proposed for the expression of glutamatergic LTP (Isaac et al., 1995; Liao et al., 1995). Whatever the precise mechanism of LTD $_{\text {GABA-A }}$ expression in neonates, our results stand in clear contrast with the data regarding NMDA-dependent LTD of GABAergic synaptic transmission in adult hippocampus, in which the expression results from a uniform downregulation of postsynaptic $\mathrm{GABA}_{\mathrm{A}}$ receptors related to postsynaptic dephosphorylating processes (Stelzer et al., 1987; Wang and Stelzer, 1996).

\section{Conclusion}

In the present report we have studied the mechanisms of induction and expression of $\mathrm{LTD}_{\mathrm{GABA}-\mathrm{A}}$. Important issues concern the 
possible function that $\mathrm{LTD}_{\mathrm{GABA}-\mathrm{A}}$ might serve during development and the natural stimuli that would lead to $\mathrm{LTD}_{\mathrm{GABA}-\mathrm{A}}$. Recent studies strongly suggest that the mechanisms leading to LTD or LTP of synaptic transmission also contribute to the establishment of appropriate synaptic connections within the developing brain (Goodman and Shatz, 1993; Isaac et al., 1997; Constantine-Paton and Cline, 1998; Fitzsimonds and Poo, 1998). Initially established for glutamatergic synaptic transmission, this link may be extended to the GABAergic synapses. Thus, LTD $_{\text {GABA-A }}$ is only induced at a time when GABA acts as an excitatory transmitter (McLean et al., 1996). At that developmental stage, spontaneous synaptic activity is dominated by the presence of spontaneous network-driven events termed GDPs (Ben-Ari et al., 1989). These GDPs lead to a coincident depolarization of postsynaptic neurons and presynaptic firing of GABAergic and glutamatergic terminals (Khazipov et al., 1997) and reveal a natural co-activation of $\mathrm{GABA}_{\mathrm{A}}$ and NMDA receptors followed by a subsequent rise in $\left[\mathrm{Ca}^{2+}\right]_{\mathrm{i}}$ (Leinekugel et al., 1997). These spontaneous GDPs may represent the physiological network-driven activity leading to activity-dependent patterning of GABAergic synaptic transmission through LTD-like mechanisms in the developing hippocampus.

\section{REFERENCES}

Alger BE, Pitler TA, Wagner JJ, Martin LA, Morishita W, Kirov SA, Lenz RA (1996) Retrograde signalling in depolarization-induced suppression of inhibition in rat hippocampal CA1 cells. J Physiol (Lond) 496:197-209.

Amaral DG, Dent JA (1981) Development of the mossy fibers of the dentate gyrus: light and electron microscopic study of the mossy fibers and their expansions. J Comp Neurol 195:51-86.

Bear MF, Malenka RC (1994) Synaptic plasticity: LTP and LTD. Curr Opin Neurobiol 4:389-399.

Ben-Ari Y, Represa A (1990) Brief seizure episodes induce long-term potentiation and mossy fibre sprouting in the hippocampus. Trends Neurosci 13:312-318.

Ben-Ari Y, Cherubini E, Corradetti R, Gaïarsa J-L (1989) Giant synaptic potentials in immature rat CA3 hippocampal neurones. J Physiol (Lond) 416:303-325.

Ben-Ari Y, Khazipov R, Leinekugel X, Caillard O, Gaïarsa J-L (1997) $\mathrm{GABA}_{\mathrm{A}}, \mathrm{NMDA}$ and AMPA receptors: a developmentally regulated "ménage a trois." Trends Neurosci 20:523-529.

Caillard O, Ben-Ari Y, Gaïarsa J-L (1999) Long-term potentiation of GABAergic synaptic transmission in neonatal rat hippocampus J Physiol (Lond) 518:109-119.

Charpier S, Behrends JC, Triller A, Faber DS, Korn H (1995) "Latent" inhibitory connections become functional during activity-dependent plasticity. Proc Natl Acad Sci USA 92:117-120.

Constantine-Paton M, Cline HT (1998) LTP and activity dependent synaptogenesis: the more alike they are, the more different they become. Curr Opin Neurobiol 8:139-148.

Crepel V, Hammond C, Krnjevic K, Chinestra P, Ben-Ari Y (1993) Anoxia-induced LTP of isolated NMDA receptor-mediated synaptic responses. J Neurophysiol 69:1774-1778.

Faber DS, Korn H (1991) Applicability of the coefficient of variation method for analysing synaptic plasticity. Biophys J 60:1288-1294.

Fitzsimonds RM, Poo MM (1998) Retrograde signalling in the development and modification of synapses. Physiol Rev 78:143-170.

Glitsch M, Llano I, Marty A (1996) Glutamate as a candidate retrograde messenger at interneurone-Purkinje cell synapses of rat cerebellum. J Physiol (Lond) 497:531-537.

Goodman CS, Shatz CJ (1993) Developmental mechanisms that generate precise patterns of neuronal connectivity. Cell 72:77-98.

Isaac JTR, Nicoll RA, Malenka RC (1995) Evidence for silent synapses: implications for the expression of LTP. Neuron 15:427-434.

Isaac JTR, Crair MC, Nicoll RA, Malenka RC (1997) Silent synapses during development of thalamocortical inputs. Neuron 18:269-280.

Kano M (1996) Long-lasting potentiation of GABAergic inhibitory synaptic transmission in cerebellar Purkinje cells: its properties and possible mechanisms. Behav Brain Sci 19:354-364.

Kano M, Rexhausen U, Dreessen J, Konnerth A (1992) Synaptic excitation produces a long-lasting rebound potentiation of inhibitory synaptic signals in cerebellar Purkinje cells. Nature 356:601-604.

Khazipov R, Leinekugel X, Khalilov I, Gaïarsa J-L, Ben-Ari Y (1997) Synchronization of GABAergic interneuronal network in CA3 subfield of neonatal rat hippocampal slices. J Physiol (Lond) 498:763-772.

Komatsu Y (1996) $\mathrm{GABA}_{\mathrm{B}}$ receptors, monoamine receptors, and postsynaptic inositol trisphosphate-induced $\mathrm{Ca}^{2+}$ release are involved in the induction of long-term potentiation at visual cortical inhibitory synapses. J Neurosci 16:6342-6352.

Komatsu Y, Iwakiri M (1993) Long-term modification of inhibitory synaptic transmission in developing visual cortex. NeuroReport 4:907-910.

Leinekugel X, Medina I, Khalilov I, Ben-Ari Y, Khazipov R (1997) $\mathrm{Ca}^{2+}$ oscillations mediated by the synergistic excitatory actions of $\mathrm{GABA}_{\mathrm{A}}$ and NMDA receptors in the neonatal hippocampus. Neuron 18:243-255.

Liao D, Hessler NA, Malinow R (1995) Activation of postsynaptically silent synapses during pairing-induced LTP in CA1 region of hippocampal slice. Nature 375:400-404.

Llano I, Leresche N, Marty A (1991) Calcium entry increases the sensitivity of cerebellar Purkinje cells to applied GABA and decreases inhibitory synaptic currents. Neuron 6:565-574.

Manabe T, Nicoll RA (1994) Long-term potentiation: evidence against an increase in transmitter release probability in the CA1 region of the hippocampus. Science 265:1888-1892.

Manabe T, Wyllie DJ, Perkel DJ, Nicoll RA (1993) Modulation of synaptic transmission and long-term potentiation: effects on paired pulse facilitation and EPSC variance in the CA1 region of the hippocampus. J Neurophysiol 70:1451-1459.

McLean HA, Rovira C, Ben-Ari Y, Gaïarsa J-L (1995) NMDAdependent $\mathrm{GABA}_{\mathrm{A}}$-mediated polysynaptic potentials in the neonatal rat hippocampal CA3 region. Eur J Neurosci 7:1442-1448.

McLean HA, Caillard O, Ben-Ari Y, Gaïarsa J-L (1996) Bidirectional plasticity expressed by GABAergic synapses in the neonatal rat hippocampus. J Physiol (Lond) 496:471-477.

Miledi R (1966) Strontium as a substitute for calcium in the process of transmitter release at the neuromuscular junction. Nature 212:1233-1234.

Mogul DJ, Fox AP (1991) Evidence for multiple types of Ca2+ channels in acutely isolated hippocampal CA3 neurones of the guinea-pig. J Physiol (Lond) 433:259-281.

Morishita W, Alger BE (1997) Sr2+ supports depolarization-induced suppression of inhibition and provides new evidence for a presynaptic expression mechanism in rat hippocampal slices. J Physiol (Lond) 505:307-317.

Morishita W, Sastry BR (1993) Long-term depression of IPSPs in rat deep cerebellar nuclei. NeuroReport 4:719-722.

Morishita W, Sastry BR (1996) Postsynaptic mechanisms underlying long-term depression of GABAergic transmission in neurons of the deep cerebellar nuclei. J Neurophysiol 76:59-68.

Morishita W, Kirov, SA, Alger BE (1998) Evidence for metabotropic glutamate receptor activation in the induction of depolarizationinduced suppression of inhibition in hippocampal CA1. J Neurosci 18:4870-4882.

Nowak L, Bregestovski P, Ascher P, Herbet A, Prochiantz A (1984) Magnesium gates glutamate-activated channels in mouse central neurones. Nature 307:462-465.

Nusser Z, Hajos N, Somogyi P, Mody I (1998) Increased number of synaptic GABA(A) receptors underlies potentiation at hippocampal inhibitory synapses. Nature 395:172-177.

Oda Y, Charpier S, Murayama Y, Suma C, Korn H (1995) Long-term potentiation of glycinergic inhibitory synaptic transmission. J Neurophysiol 74:1056-1074.

Oliet SHR, Malenka RC, Nicoll RA (1996) Bidirectional control of quantal size by synaptic activity in the hippocampus. Science 271:1294-1297.

Oliet SHR, Malenka RC, Nicoll RA (1997) Two distinct forms of long- 
term depression coexist in CA1 hippocampal pyramidal cells. Neuron 18:969-982.

Reyes M, Stanton PK (1996) Induction of hippocampal long-term depression requires release of $\mathrm{Ca}^{2+}$ from separate presynaptic and postsynaptic intracellular stores. J Neurosci 16:5951-5960.

Rumpel E, Behrends JC (1999) Sr2+-dependent asynchronous evoked transmission of rat striatal inhibitory synapses in vitro. J Physiol (Lond) 514.2:447-458.

Stelzer A, Slater NT, ten Bruggencate G (1987) Activation of NMDA receptors blocks GABAergic inhibition in an in vitro model of epilepsy. Nature 326:698-701.

Super H, Soriano E (1994) The organisation of the embryonic and early postnatal murine hippocampus. II. Development of entorhinal, commissural and septal connections studied with the lipophilic tracer DiI. J Comp Neurol 344:101-120.

Thompson SM, Gähwiler BH (1992) Comparison of the actions of baclofen at pre- and postsynaptic receptors in the rat hippocampus in vitro. J Physiol (Lond) 451:329-345.

Thompson SM, Wong RKS (1991) Development of calcium current subtypes in isolated rat hippocampal pyramidal cells. J Physiol (Lond) 439:671-689.

Wang JH, Stelzer A (1996) Shared calcium signalling pathways in the induction of long-term potentiation and synaptic disinhibition in CA1 pyramidal cell dendrites. J Neurophysiol 75:1687-1702. 